\title{
Lymphocyte Cytotoxicity to Cultured Rat Liver Gells in Patients with Chronic Liver Diseases
}

\author{
Akitaka Nonomura, Toshinisa Shintani and Goroku Ohta \\ Department of Pathology, School of Medicine, Kanazawa \\ University, Kanazawa 920
}

\begin{abstract}
Nonomura, A., Shintant, T. and OHTa, G. Lymphocyte cytotoxicity to Cultured Rat Liver Cells in Patients with Chronic Liver Diseases. Tohoku J. exp. Med., 1978, 126 (2), 159-171 — Microcytotoxicity assay revealed that peripheral blood lymphocytes from patients with chronic active hepatitis were cytotoxic against cultured rat liver cells established by Coon in 1968. Non E-rosette forming cells were cytotoxic in 26 of 28 patients $(93 \%)$ with chronic active hepatitis, whereas E-rosette forming cells were cytotoxic in only 1 of them. Either an addition of $10 \mu \mathrm{g} /$ well of aggregated IgG to non E-rosette forming cell culture or a preincubation of non E-rosette forming cells with $100 \mu \mathrm{g} / \mathrm{ml}$ of aggregated IgG significantly reduced the cytotoxicity from $62.9 \pm 12.8 \%$ to $32.8 \pm 11.6 \%$ or to $25.6 \pm 11.3 \%$ $(p<0.001)$. An addition of antihuman $\operatorname{IgG} / \mathrm{Fc}$ also reduced the cytotoxicity to $37.4 \pm 17.2 \%$. Significant cytotoxicity of positively selected EA-rosette forming cells was observed in 4 of 10 patients with chronic active hepatitis and that of positively selected EAC-rosette forming cells was demonstrated in 3, whereas in any of these patients neither non EA-rosette forming cells nor non EAC-rosette forming cells were cytotoxic. Cultured liver cells used in this study were seen to possess insoluble liver specific antigen on their surface membranes, but not soluble liver specific lipoprotein of Meyer zum Büschenfelde, by using an indirect immunofluorescence technique. These results suggested that effector cells are Fcreceptor-bearing cells and that the mechanism of the reaction may be mediated in an antibody-dependent cell-mediated reaction directed against insoluble liver specific membrane antigen(s) rather than soluble one. — cytotoxicity; Coon cell; non E-RFC; IHSM
\end{abstract}

Chronic and continuing injury to liver cells in certain individuals results in cirrhosis. So far the mechanisms of liver cell destruction are not clear. In patients of chronic carriage of hepatitis $B$ virus (HBV), host-immune response to the infectious agents may cause continuing liver cell damage (Dudley et al. 1972; Eddleston and Williams 1974). On the other hand, host-immune response to the hepatocyte-surface membrane is another important mechanism causing liver cell damage (Cochrane et al. 1976; Lee et al. 1975; Ohta et al. 1976). Previous studies in our laboratory have demonstrated that cellular immune response to HBsAg can initiate an autoimmune reaction to the hepatocyte-surface membranes in many cases of chronic hepatitis (Ohta et al. 1976). And we emphasized the importance of

Received for publication, January 25, 1978.

Correspondence: Dr. A. Nonomura, Department of Pathology, School of Medicine, Kanazawa University, Kanazawa, Japan. 
the insoluble hepatocyte-surface membranes (IHSM) as a target site of immune reaction. IHSM has a liver specific component which is different from soluble liver specific membrane lipoprotein (LSP) reported by Meyer zum Büschenfelde and Miescher (Oht et al. 1976; Meyer zum Büschenfelde and Miescher 1972).

Evidence has been accumulated that peripheral blood lymphocytes from patients with chronic active hepatitis closely contact in vitro with liver cell membranes of several sources and then destroy them; rabbit hepatocytes (Thomson et al. 1974; Cochrane et al. 1976), Chang liver cells (Wands and Isselbacher 1975; Wands et al. 1975), autologous liver cells (Wands and Isselbacher 1975; Geubel et al. 1976) and human autochthonous liver cells (Paronetto and Vernace 1975). In such a reaction LSP of the membranes was thought by some investigators to be important in the production of liver cell injury (Thomson et al. 1974; Cochrane et al. 1976).

The present report deals with cytotoxicity of lymphocytes from patients with chronic liver diseases against cultured rat liver cells which were established by Coon in 1968.

\section{Materials and Methods}

\section{Patients}

The studies were performed on patients with chronic persistent hepatitis (CPH) (7 cases), chronic active hepatitis (CAH) (28 cases), liver cirrhosis (LC) (7 cases) and normal controls ( 12 cases). No patients in this series were receiving steroids or immunosuppressive drugs. Further information is presented in Table 1. A diagnosis was made by histological features of needle liver biopsies, liver function tests and clinical courses and a classification of chronic hepatitis was made based upon Acapulco's criteria (Chalmers et al. 1974).

TABLE 1. Results of the cytotoxicity test of non E-RFC using Coon liver cells as target cells in patients with chronic liver diseases with and without $\mathrm{HBs} A \mathrm{~g}$

\begin{tabular}{|c|c|c|c|}
\hline \multirow{2}{*}{ Diagnosis } & \multirow{2}{*}{ Number of cases } & \multicolumn{2}{|c|}{$\begin{array}{c}\text { Number of cases with significant } \\
\text { cytotoxicity* }\end{array}$} \\
\hline & & Number & $\%$ \\
\hline \multicolumn{4}{|c|}{ Chronic persistent hepatitis } \\
\hline HBsAg-negative & 6 & 2 & 33 \\
\hline HBsAg-positive & 1 & 0 & 0 \\
\hline \multicolumn{4}{|c|}{ Chronic active hepatitis } \\
\hline HBsAg-negative & 15 & 15 & 100 \\
\hline HBsAg-positive & 13 & 11 & 85 \\
\hline \multicolumn{4}{|l|}{ Liver cirrhosis } \\
\hline HBsAg-negative & 3 & 1 & 33 \\
\hline HBsAg-positive & 4 & 0 & 0 \\
\hline Normal† & 12 & 0 & 0 \\
\hline
\end{tabular}

* \% cytotoxicity larger than two standard deviations from the mean of normal control.

$\dagger$ Five individuals were served as control in the cytotoxicity test of non E-RFC and the remainders were served as control for EA-RFC, non EA-RFC, EAC-RFC and non EAC-RFC. 


\section{Statistical analysis}

Comparisons between groups were made using Student's $t$-test and the $\chi^{2}$ test.

Media

Cell culture was performed using Eagle's minimal essential medium (Grand Island Biological Company, USA) supplemented with $10 \%$ heat-inactivated fetal calf serum (Grand Island Biological Company, USA), $100 \mathrm{U}$ of penicillin/ml and $100 \mu \mathrm{g}$ of streptomycin/ml (MEM-FCS). For cell washing, Hanks balanced salt solution (HBSS), pH 7.4, supplemented with penicillin and streptomycin was used.

\section{Whole lymphocyte fraction (WLF)}

Peripheral blood mononuclear cells were obtained by floatation sedimentation using a Ficoll-Paque (F-P) (Pharmacia Fine Chemicals, Sweden) gradient (Böyum 1968). The cells were washed three times with HBSS. The resulting cell population contained $97 \%$ lymphocytes and more than $99 \%$ of the cells were viable when judged by trypan blue exclusion. After the last wash cells were resuspended in an appropriate volume of MEMFCS.

\section{Rosette forming procedures}

E-rosette formation was made by the method of Yata et al. (1973). Washed sheep erythrocytes $(E)$ were diluted with fetal calf serum to give a final concentration of $2 \times 10^{8}$ cells/ml. Lymphocytes of WLF were also resuspended in fetal calf serum at a concentration of $5 \times 10^{6}$ cells $/ \mathrm{ml}$. Equal volumes of these two suspensions were mixed, left at $37^{\circ} \mathrm{C}$ for $15 \mathrm{~min}$, centrifuged at $150 \times \mathrm{g}$ for $5 \mathrm{~min}$ and then incubated in ice water for $1 \mathrm{hr}$.

EA-rosette formation was made by the methods of Parish and Hayward (1974). Washed $\mathrm{E}$ was resuspended in HBSS at a concentration of $5 \times 10^{8}$ cells $/ \mathrm{ml}$. Equal volumes of $\mathbf{E}$ suspension and the highest subagglutination concentration of $7 \mathrm{~S}$ fraction of a rabbit anti-E serum diluted with HBSS were incubated at $37^{\circ} \mathrm{C}$ for $30 \mathrm{~min}$. The sensitized cells (EA) were then washed three times $(200 \times \mathrm{g}, 10 \mathrm{~min})$ with HBSS and resuspended at a concentration of $5 \times 10^{8}$ cells $/ \mathrm{ml}$ with MEM-FCS. Equal volumes of EA and lymphocyte suspension of WLF $\left(10^{7}\right.$ cells $\left./ \mathrm{ml}\right)$ were mixed and rotated at $30 \mathrm{rpm}$ at $37^{\circ} \mathrm{C}$ for $15 \mathrm{~min}$.

EAC-rosette was formed by the method adapted from Parish and Hayward (1974). Equal volumes of a $5 \times 10^{8}$ cells $/ \mathrm{ml}$ suspension of washed $\mathbf{E}$ in HBSS and the highest subagglutination concentration of the $19 \mathrm{~S}$ fraction of a rabbit anti-E serum were incubated at $37^{\circ} \mathrm{C}$ for $20 \mathrm{~min}$. The sensitized cells $(\mathrm{EA})$ were then washed twice $(200 \times \mathrm{g}, 10$ min) with HBSS and resuspended in a concentration of $5 \times 10^{8} \mathrm{cells} / \mathrm{ml}$. Equal volumes of a $5 \times 10^{8}$ cells $/ \mathrm{ml}$ suspension of $\mathrm{EA}$ and a $1 / 10$ dilution of fresh mouse serum were then incubated at $37^{\circ} \mathrm{C}$ for $20 \mathrm{~min}$. The resultant red cells $(\mathrm{EAC})$ were then washed twice with HBSS, resuspended with MEM-FCS at a concentration of $1 \times 10^{8}$ cells $/ \mathrm{ml}$. EAC-rosettes were formed by mixing an equal volume of this EAC suspension with the mononuclear cells of WLF $\left(3 \times 10^{6} \mathrm{cells} / \mathrm{ml}\right)$ and rotating the mixture at $30 \mathrm{rpm}$ for $15 \mathrm{~min}$ at $37^{\circ} \mathrm{C}$.

\section{Separation of rosetting cells from non-rosetting cells}

The mixture containing either EA- or EAC-rosette forming cells was then layered gently onto F.P and spun at $400 \times \mathrm{g}$ for $30 \mathrm{~min}$ at room temperature and the mixture containing E-rosettes at $4^{\circ} \mathrm{C}$. Cell fractions lying at the bottom of the tubes were referred to as E-rosette forming cells (E-RFC), EA-rosette forming cells (EA-FRC) and EAC-rosette forming cells (EAC-RFC), respectively. They were recovered by lysis of the $\mathrm{E}$ with a $0.83 \% \mathrm{NH}_{4} \mathrm{Cl}$ in $20 \mathrm{mM}$ Tris buffer (pH 7.4) for $5 \mathrm{~min}$ and were then washed twice with HBSS and resuspended in MEM-FCS at a concentration of $3 \times 10^{6}$ cells $/ \mathrm{ml}$. Cell fractions remaining at the top of the F-P were referred to as non E.RFC, non EA-FRC and non EACRFC, respectively. They were collected and washed twice with HBSS and resuspended in MEM-FCS at a concentration of $3 \times 10^{8} \mathrm{cells} / \mathrm{ml}$. 


\section{Target cells}

Target cells (Coon liver cells) were the serially propagated hepatic parenchymal cells from adult rat livers, originally established by Coon in 1968 from clonal culture of adult rat liver cells. Using a method of immunofluorescence technique for detection of liver specific insoluble rat hepatocyte-surface antigens, prepared by Berman's method (Berman et al. 1969) as previously described (Ohta et al. 1976), Coon liver cells mostly showed finely granular specific fluorescence of their surface membranes (Fig. 1). The specificity of the antiserum to insoluble rat hepatocyte-surface antigen was described previously (Ohta et al. 1976). Rabbit antibody to soluble rat liver specific antigens (LSP) of Meyer zum Büschenfelde and Miescher (1972), however, did not react with the same surface membranes using an indirect immunofluorescence method. So we suggest that the Coon liver cell strain bears at least a liver specific insoluble antigen on their cell surface membranes whereas LSP has been lost during years in culture probably because of mutational changes or modification by antigen induced by viral or other unknown agents (Edgington and Chisari 1975). Fibroblasts obtained from rat fetus by the method of Ruddle and Waksman (1968) were also used as target cells for the lymphocyte cytotoxicity test.

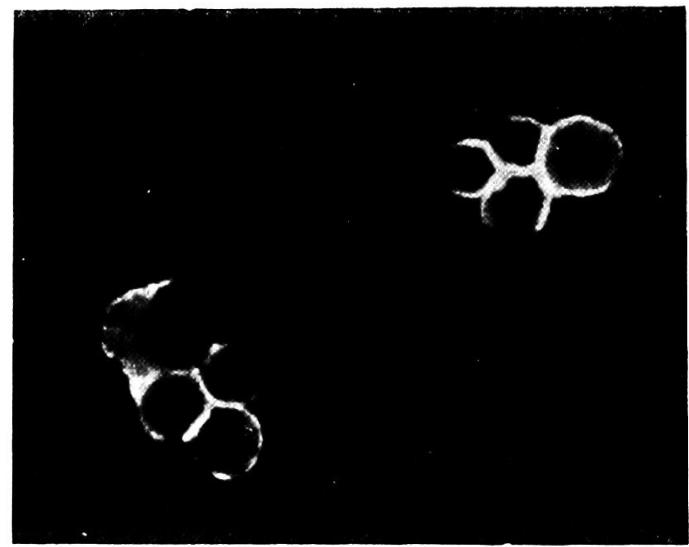

Fig. 1. Membrane immunofluorescence of Coon liver cells by means of indirect immunofluorescence method using rabbit anti-liver specific insoluble hepatocytesurface membranes antibody.

Target cells, either Coon liver cells or fetal fibroblasts, revealed to maintain monolayer in MEM-FCS and were harvested by treatment with $0.02 \%$ EDTA and $0.05 \%$ trypsin in HBSS. After being washed with HBSS and resuspended in fresh MEM-FCS, the cells were counted and diluted to a concentration of $1 \times 10^{4}$ cells $/ \mathrm{ml}$. More than $95 \%$ of Coon liver cells and more than $93 \%$ of fibroblasts were seen to be viable by the trypan blue exclusion method.

\section{Cytotoxicity test}

The method of Takasugi and Klein (1970) was used throughout the experiment. The above-mentioned target cell suspension, $10 \mu \mathrm{l}$, was placed into the wells of a plastic microtest tissue culture plate (Falcon, 3034. USA) by using a microautopipette (Erma Co., Ltd., Japan), and incubated in a water-jacketed incubator at $37^{\circ} \mathrm{C}$ in an atmosphere of $95 \%$ air and $5 \% \mathrm{CO}_{2}$. After $6 \mathrm{hr}$ or more, target cell micromonolayers were examined and counted, and then added with $10 \mu \mathrm{l}$ of the lymphocyte suspension to yield a ratio of target cell to lymphocyte of $1: 300$. For blocking experiments, suspernatant of the well was carefully removed and $10 \mu \mathrm{l}$ of the blocking media was added before adding lymphocytes, as described 
below. After incubation for $48 \mathrm{hr}$ at $37^{\circ} \mathrm{C}$, the plates were inverted for a further $2 \mathrm{hr}$ and then carefully rinsed in HBSS. After washing, living cells attached to the floor of the well were fixed with ethanol for $5 \mathrm{~min}$ and were stained with Giemsa. A number of target cells remaining in each well was counted. Each experimental procedure was performed with at least 6 replicate wells. Percent eytotoxicity was determined as follows:

$$
\% \text { cytotoxicity }=100-\frac{\text { mean number of cells in test }}{\text { mean number of cells in target cell control }} \times 100
$$

\section{Blocking test of cytotoxicity}

Blocking with aggregated IgG. IgG was separated from normal human serum by a precipitation technique using ammonium sulfate. Aggregation was produced by heating exactly at $63^{\circ} \mathrm{C}$ for $15 \mathrm{~min}$, and gross precipitates were removed by centrifugation at $500 \times \mathrm{g}$. After measurement of the protein concentration the supernatant was diluted with MEM-FCS

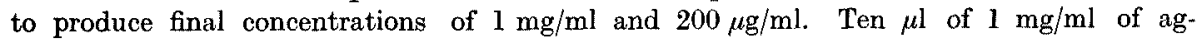
gregated IgG were added to a well (10 $\mu \mathrm{g}$ of aggregated IgG/well) at the time of lymphocyte adding. Another blocking experiment was performed with aggregated IgG; namely, lymphocyte suspension of $1 \times 10^{\circ}$ cells $/ \mathrm{ml}$ was mixed with an equal volume of $200 \mu \mathrm{g} / \mathrm{ml}$ of aggregated IgG and incubated at $37^{\circ} \mathrm{C}$ for $30 \mathrm{~min}$. After washing carefully with MEM-FCS, lymphocytes were resuspended with MEM-FCS to produce a final concentration of $3 \times 10^{6}$ cells $/ \mathrm{ml}$.

Blocking test with anti-human IgG/Fc. It has been shown that antibody-dependent cell-mediated cytotoxicity is inhibited by anti-IgG/Fc (Austin and Daniels 1976). Therefore, we sought to determine the effect of anti-human IgG/Fc on the lymphocyte cyto. toxicity test. Anti-human IgG/Fe (Hoechst, Batch No. 2934 E.W., Germany) was diluted 500 times with MEM-FCS after centrifugation at $105,000 \times \mathrm{g}$ for $30 \mathrm{~min}$ to remove aggregated IgG. Ten $\mu$ l of diluted anti-human IgG/Fc were added to a well simultaneously with the addition of lymphocytes.

\section{Results}

\section{Cytotoxicity of whole lymphocyte fraction}

When Coon liver cells were used as target cells, the mean \% cytotoxicity of the peripheral whole lymphocytes from patients with $\mathrm{CPH}, \mathrm{CAH}, \mathrm{LC}$ and normal control was $6.4 \pm 9.4 \%$ (mean \pm s.D.), $24.4 \pm 5.9 \%, 1.1 \pm 13.8 \%$ and $-11.8 \pm 14.9 \%$, respectively. The \% cytotoxicity of $\mathrm{CAH}$ was statistically significant in comparison with that of normal control ( $p<0.001$, Fig. 2). Significant cytotoxicity, judged by a value more than mean +2 s.D. of the control, was demonstrated in 6 of 8 patients with $\mathrm{CAH}(75 \%), 1$ of 6 patients with $\mathrm{CPH}$, and 1 of 6 patients with LC.

\section{Cytotoxicity of $E-R F C$}

The mean \% cytotoxicity of E-RFC against Coon liver cells in patients with $\mathrm{CPH}, \mathrm{CAH}, \mathrm{LC}$ and normal control was $-7.3 \pm 12.4 \%,-1.2 \pm 25.8 \%,-12.8 \pm 11.1 \%$ and $-8.4 \pm 15.9 \%$, respectively. There was no significant cytotoxic activity in any group of the liver-diseased patients, as compared with normal controls. Only 1 of 16 patients with $\mathrm{CAH}$ showed a significant cytotoxicity of $36.3 \%$ (Fig. 3).

\section{Cytotoxicity of non $E-R F C$}

As shown in Fig. 4, the mean \% cytotoxicity in patients with CPH, CAH, LC and normal control was $22.3 \pm 21.8 \%, 44.9 \pm 16.5 \%, 23.1 \pm 27.4 \%$ and $16.8 \pm 4.4 \%$, 


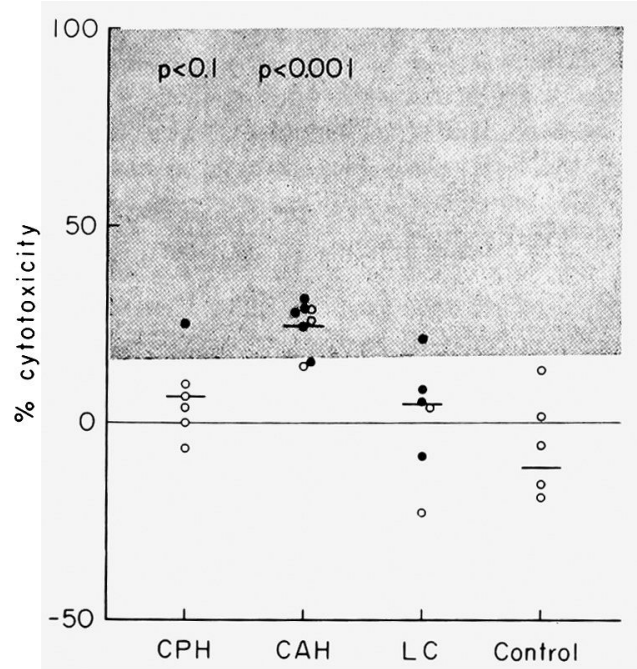

Fig. 2. The results of cytotoxocity test of the whole lymphocyte fraction from patients with chronic persistent hepatitis $(\mathrm{CPH})$, chronic active hepatitis $(\mathrm{CAH})$, liver cirrhosis (LC) and normal controls (Control). Coon liver cells were used as target cells.

HBsAg-positive case; $O$, HBsAg-negative case; 3 , range more than mean+2s.D. of the control.

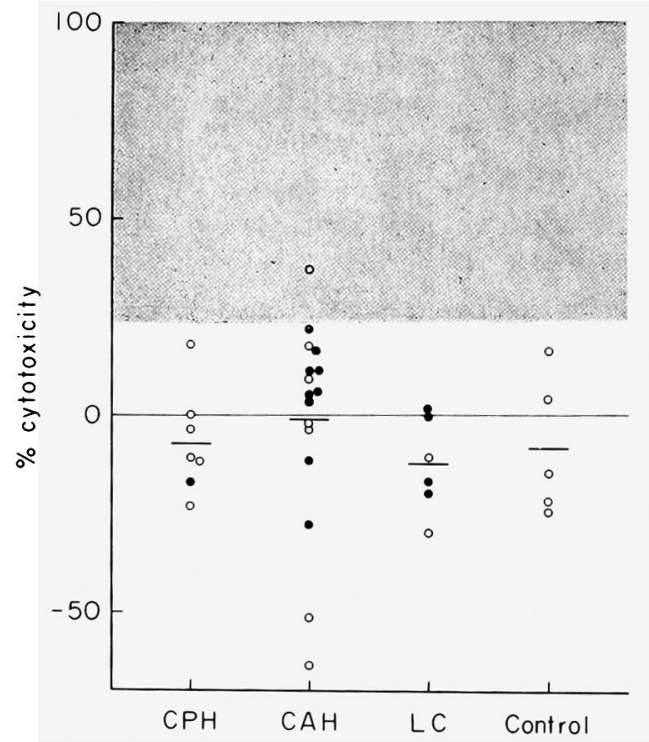

Fig. 3. The results of cytotoxicity test of E-RFC from patients with chronic liver diseases and normal controls. Coon liver cells were used as target cells. Abbreviations are the same as in Fig. 2.

-, HBsAg-positive case; O, HBsAg-negative case; of the control.

respectively. A highly significant elevation of mean $\%$ cytotoxicity was observed in patients with $\mathrm{CAH}$, compared with that of normal control $(p<0.001)$, but not in patients with either CPH or LC. Significant cytotoxicity, larger than mean value 


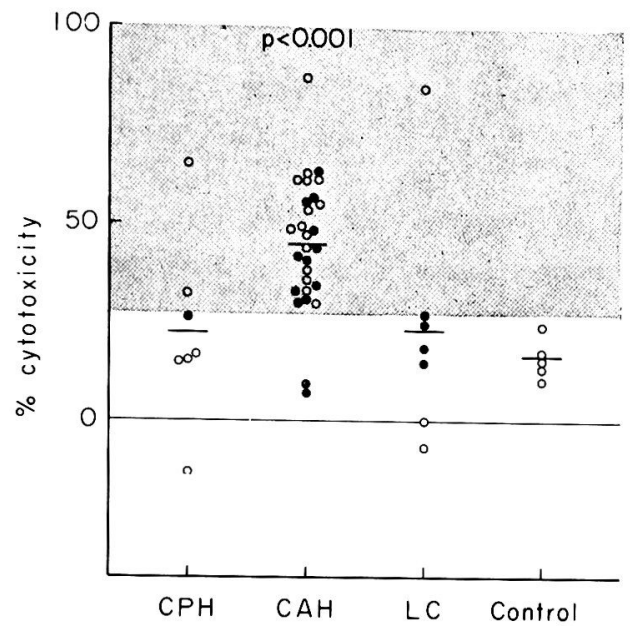

Fig. 4. The results of cytotoxicity test of non E-RFC from patients with chronic liver diseases. Coon liver cells were used as target cells. Abbreviations are the same as in Fig. 2.

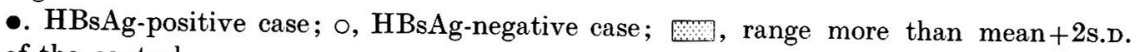
of the control.

+2 S.D. of normal control, was demonstrated in 26 of 28 patients $(93 \%)$ with $\mathrm{CAH}$, 2 of 7 patients with CPH and 1 of 7 patients with LC (Fig. 4., Table 1.). A mean $\%$ cytotoxicity in patients with $\mathrm{CAH}$ of $\mathrm{HBsAg}$-positive cases was $37.8 \pm 16.1 \%$ and that of HBsAg-negative $\mathrm{CAH}$ was $51.0 \pm 14.2 \%$, indicating a slight degree of statistical significance between both groups $(p<0.05)$.

Cytotoxicity test with non $E-R F C$ from patients with $C A H$ against rat fibroblasts

A comparison was made in cytotoxicity of non E-RFC from 9 patients with $\mathrm{CAH}$ between against Coon liver cells and fetal fibroblasts, used as target cells. A mean \% cytotoxicity against Coon liver cells was $48.5 \pm 19.3 \%$ and that against rat fibroblasts was $-83.9 \pm 34.6 \%$. This indicated that none of the patients with significant cytotoxicity against Coon liver cells showed cytotoxic activity against rat fibroblasts (Fig. 5).

\section{Blocking test of cytotoxicity with aggregated IgG and antihuman IgG/Fc}

Blocking tests were performed in patients with $\mathrm{CAH}$ whose non $\mathrm{E}-\mathrm{RFC}$ revealed significant cytotoxicity against Coon liver cells. As shown in Fig. 6, non E-RFC without blocking treatment showed \% cytotoxicity of $62.9 \pm 12.8 \%$. An addition of aggregated IgG into the culture medium yielded a significant reduction of $\%$ cytotoxicity to $32.8 \pm 11.6 \%(p<0.001)$ (Fig. 6, right column of the left figure). Preincubation with aggregated IgG also reduced cytotoxicity from $62.9 \pm 12.8 \%$ to $25.6 \pm 11.3 \%(p<0.001)$ (Fig. 6, middle column of the left figure). Anti-human $\mathrm{IgG} / \mathrm{Fc}$ added also reduced cytotoxicity to $37.4 \pm 17.2 \%(p<0.001)$ (Fig. 6., right figure). 


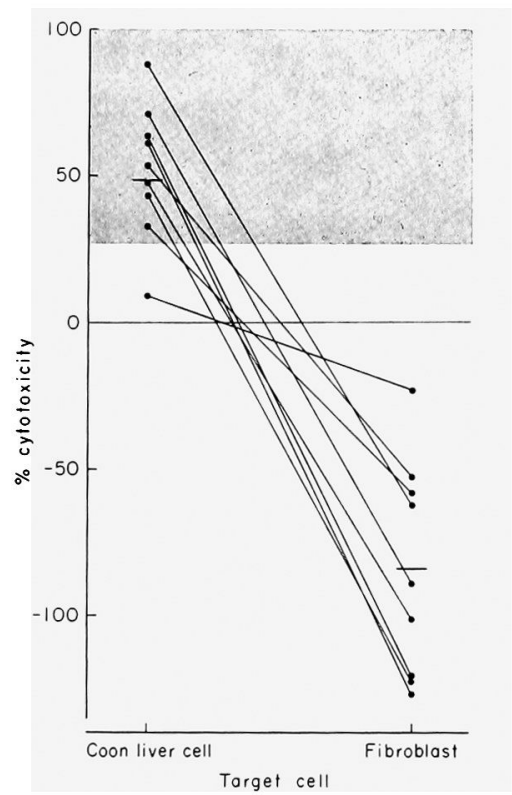

Fig. 5. Cytotoxicity of non E-RFC from patients with chronic active hepatitis. Compare cytotoxicity against Coon liver cells and against rat fibroblasts. ․ㅏㅁ, range more than mean +2 s.D. of the control.
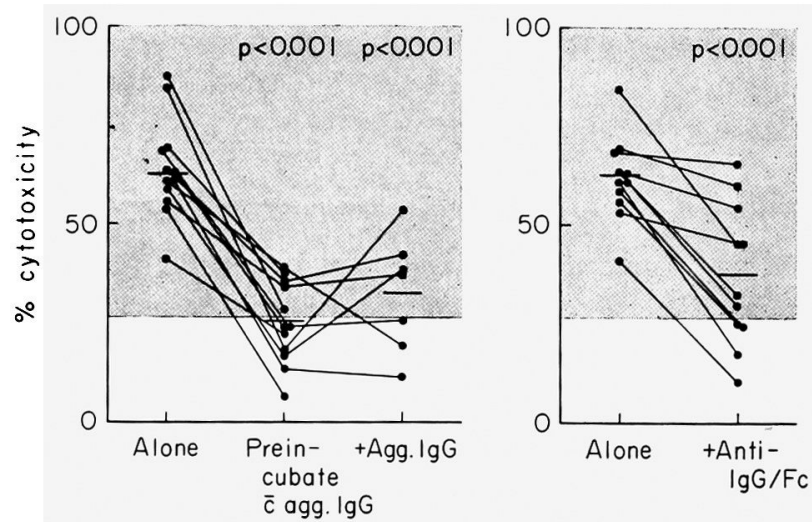

Fig. 6. Blocking of the cytotoxicity with aggregated IgG (left) and anti-human IgG/Fc (right). \% cytotoxicity before (Alone) and after preincubation of non E-RFC with $100 \mu \mathrm{g} / \mathrm{ml}$ of aggregated IgG (left figure, middle column) and addition of $10 \mu \mathrm{g} / \mathrm{well}$ of aggregated IgG (left figure, right column). \% cytotoxicity before (Alone) and after addition of $10 \mu \mathrm{l}$ of anti-human IgG/Fc (1/500 dilution of original antiserum, final antiserum activity of $1 / 1000$ of original antiserum/well, right figure, right column). , range more than mean +2 s.D. of the control.

Cytotoxicity test with $E A-R F C$, non EA-RFC, EAC-RFC and non EAC-RFC

Cytotoxicity tests of these lymphocyte fractions were simultaneously performed in 10 patients with $\mathrm{CAH}$ and 7 of normal control. Mean \% cytotoxicity of EA-RFC, non EA-RFC, EAC-RFC and non EAC-RFC from normal controls was 
$17.8 \pm 24.5 \%, \quad-20.6 \pm 10.7 \%, \quad 0.18 \pm 14.9 \% \quad$ and $\quad-15.9 \pm 18.7 \%, \quad$ respectively, whereas mean $\%$ cytotoxicity of those from patients with $\mathrm{CAH}$ was $53.6 \pm 19.2 \%$, $-29.2 \pm 13.5 \%, 15.3 \pm 25.4 \%$ and $-26.0 \pm 12.4 \%$, respectively (Fig. 7). Thus only EA-RFC from patients with $\mathrm{CAH}$ showed statistically significant mean cytotoxic activity $(p<0.01)$ (Fig. 7 ). EAC-RFC from 3 of 10 patients with CAH showed $\%$ cytotoxicity more than mean value +2 s.D. of normal control, but the mean value of the same cells was not significant.

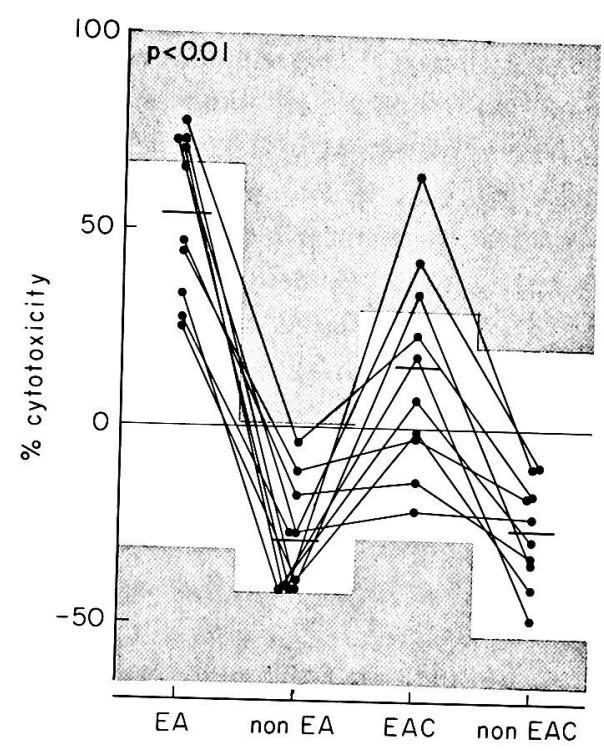

Fig. 7. The results of cytotoxicity test of EA-RFC (EA), non EA-RFC (non EA), EACRFC (EAC) and non EAC-RFC (non EAC) from patients with CAH. Coon liver cells were used as target cells. $\square$, range more than mean \pm 2 s.D. of the control.

\section{Discússion}

It has been demonstrated by some investigators that patients with chronic liver diseases, particularly those with $\mathrm{CAH}$ and primary biliary cirrhosis (PBC) had a cell-mediated immunity directed against liver extracts or liver specific antigens of hepatocyte-surface membranes (Bacon et al. 1972; Miller et al. 1972; Smith et al. 1972, 1975; Ohta et al. 1976). A high incidence of cell-mediated immunity to both HBsAg and liver specific antigens was found in HBsAg-negative patients with CAH (Lee et al. 1975; Ohta et al. 1976). And it was known that HBsAg-negative CAH developed from acute type B hepatitis in some patients (Nielsen et al. 1971; Lee et al. 1975). These studies indicated a close linkage between HBV infection and development of $\mathrm{CAH}$ even in $\mathrm{HBV}$-negative patients, and an autoimmune reaction may be initiated by HBV infection because of probable changes in antigenicity of the hepatocyte-surface membranes due to alteration of pre-existing antigens or appearance of neoantigen produced by viral genome (Edgington and Chisari 1975). 
The lymphocyte cytotoxicity test has recently been employed in patients with $\mathrm{CAH}$ and PBC (Thomson et al. 1974; Wands and Isselbacher 1975; Wands et al. 1975; Paronetto and Vernace 1975; Cochrane et al. 1976; Geubel et al. 1976). In the present study, circulating lymphocytes from patients with $\mathrm{CAH}$, when cultured in the absence of human serum, were cytotoxic to Coon rat liver cells but not at all to rat fibroblasts. This suggests strongly that cytotoxicity of the patient's lymphocytes is liver cell-specific. Significant negative values of cytotoxicity against rat fibroblasts seemed to be a non-immunologic feeder effect as described by Herberman and Oldham (1975). Studies of subfractionation of the lymphocytes indicated that the cells responsible for liver cell destruction in this assay system were non E-RFC and had Fc-receptors on their surface, evidenced from the experiment of EA-RFC. The reduction of cytotoxicity of these lymphocytes after blocking with aggregated $\operatorname{IgG}$ and antihuman $\operatorname{IgG} / \mathrm{Fc}$ further supports the concept that effector cells are Fc-receptor-bearing cells. This is in agreement, though not completely, with the data of Cochrane et al. (1976) who reported that cytotoxicity of non E-RFC against isolated rabbit hepatocytes was blocked by liver-specific membrane lipoproteins (LPS) of Meyer zum Büschenfelde. LSP, however, was not demonstrated on the surface membranes of Coon liver cells using the indirect immunofluorescence technique and our preliminary experiment indicated that LSP did not significantly block the cell-mediated reaction against Coon liver cells (in preparation).

Furthermore, it has recently been demonstrated that peripheral blood lymphocytes from patients with $\mathrm{CAH}$ were cytotoxic against Chang liver cells (Wands and Isselbacher 1975; Wands et al. 1975; Scherlock 1976), which did not possess LSP on their surface membranes enough to be positively stained by the indirect immunofluorescence method (Mutchnick et al. 1976). So it seems more reasonable to consider that liver specific antigen(s) other than LSP might be an important target antigen acting in the cytotoxicity test of non E-RFC from patients with $\mathrm{CAH}$, when used Coon or Chang liver cells as target cells. Our previous study revealed that IHSM contained liver specific antigens which differed antigenically from LSP (Ohta et al. 1976). And our recent immunofluorescence investigation revealed that 6 of 9 patients with $\mathrm{CAH}$ whose lymphocytes were cytotoxic against Coon liver cells had circulating antibody to Coon cell surface membranes (Nonomura et al. 1978). In consideration of our data presented above and the data reported by Wands and Isselbacher (1975), Wands et al. (1975) and Scherlock (1976) as to the cytotoxicity against Chang liver cells, a possibility may exist that cellular immune responses to the liver specific antigen(s) other than LPS would be involved in liver cell injury. Thus, both insoluble and soluble liver-specific surface antigens participate in the cytotoxic reaction and both antigens may play an important role in the pathogenesis of $\mathrm{CAH}$.

Our preparation of non E-RFC used as effector cells was contaminated with $3 \%$ of polymorphonuclear leukocytes and monocytes. Since polymorphonuclear leukocytes and monocytes are known to be able to mediate ADCC (Cerottini and 
Brunner 1974), a participation of these cells has not been excluded completely in this system. Therefore the pure effector population involved in this assay system remains to be clarified.

In the present cytotoxicity test of non E-RFC, however, no autologous serum is added and therefore antibody to hepatocyte surface membranes, if present in the assay system, must be derived from an alternative source as described by Cochrane et al. (1976). This may be explained by two possibilities: 1) antibody is synthesized by $\mathrm{B}$ lymphocytes during incubation with the hepatocytes or 2) Fc-receptor-bearing cells may carry membrane-bound immune complexes (Perlmann et al. 1972), containing antibody to hepatocyte-surface membranes and/or membrane-bound antibody (Miller et al. 1971; Lobo and Horwitz 1976) to the hepatocyte membrnes. In our recent preliminary experiment, non E-RFC from patients with CAH after preincubation with MEM-FCS for two days was found to lose cytotoxic activity against Coon liver cells. This result seems to suggest the latter possibility. However, attempts to demonstrate membrane-bound antibody to hepatocytesurface membranes on the surface of non E-RFC using sheep erythrocytes coated with hepatocyte-surface membranes, and membrane-bound immune complexes, containing antibody to hepatocyte surface membranes, using direct immunofluorescence with anti-liver specific IHSM have not been successful as yet. So, precise mechanisms of liver cell destruction in this in vitro assay remain to be clarified.

From our results presented here, it does not seem likely that the histocompatibility or heterologous antigens play a part in production of lymphocyte cytotoxicity in patients with $\mathrm{CAH}$ against Coon liver cells which were derived from rat liver, since the lymphocytes were not cytotoxic against rat fibroblasts and lymphocytes from control persons did not show any significant cytotoxic activity.

\section{Acknowledgment}

We would like to thank Professor N. Hattori, Dr. K. Kobayashi and Dr. Y. Kato, The First Department of Internal Medicine, Kanazawa University Hospital and Dr. G. Sugioka, Department of Internal Medince, National Kanazawa Hospital for permission to examine the blood from patients under their care. The present experiment was supported by Grant No. 248146 from the Ministry of Education, Seience and Culture, Japan.

\section{References}

1) Austin, R.M. \& Daniels, C.A. (1976) Inhibition by rheumatoid factor, anti-Fc, and staphylococcal protein $A$ of antibody-dependent cell-mediated cytolysis against herpes simplex virus-infected cells. J. Immunol., 117, 602-607.

2) Bacon, P.A., Berry, H. \& Bown, R. (1972) Cell-mediated immune reactivity in liver disease. Gut, 13, 427-429.

3) Berman, H.M., Gram, W. \& Spirtes, M.A. (1969) An improved, reproducible method of preparing rat liver plasma cell membranes in buffered isotonic sucrose. Biochim. biophys. Acta (Amst.), 183, 10-18.

4) Böyum, A. (1968) Separation of leuocytes from blood and bone marrow. Scand. $J$. clin. Lab. Invest., 21, Suppl. 97, 1-109.

5) Cerottini, J.C. \& Brunner, K.T. (1974) Cell-mediated cytotoxicity, allograft rejection, 
and tumor immunity. Adv. Immunol., 18, 67-132.

6) Chalmers, T.C., Zimmerman, H., Summerskill, W.H.J. \& Mosley, J.W. (1974) Nomenclature, diagnostic criteria and diagnostic methodology for diseases of the liver and biliary tract. In: Fogarty International Center Proceedings. No. 22, edited by $\mathrm{H}$. Popper, S. Sherlock, C.M. Leevy \& M.I., Haris pp. 21-24.

7) Cochrane, A.M.G., Moussouros, A., Thomson, A.D., Eddleston, A.L.W.F. \& Williams, R. (1976) Antibody-dependent cell-mediated ( $\mathrm{K}$ cell) cytotoxicity against isolated hepatocytes in chronic active hepatitis. Lancet, 1, 441-444.

8) Coon, H.G. (1968) Clonal culture of differentiated rat liver cells. J. Cell Biol., 39, 29a.

9) Dudley, F.J., Fox, R.A. \& Sherlock, S. (1972) Cellular immunity and hepatitisassociated, Australia antigen liver disease. Lancet, 1, 723-726.

10) Eddleston, AL.W.F. \& Williams, R. (1974) Inadequate antibody response to $\mathrm{HBAg}$ or suppressor T-cell defect in development of active chronic hepatitis. Lancet, 2, 15431545 .

11) Edgington, J.S. \& Chisari, J.V. (1975) Immunological aspects of hepatitis B virus infection. Amer. J. med. Sci., 270, 213-227.

12) Geubel, A.P., Keller, R.H., Summerskill, W.H.J., Dickson, E.R., Tomasi, T.S. \& Shorter, R.G. (1976) Lymphocyte cytotoxicity and inhibition studied with autologous liver cells; observations in chronic active liver disease and the primary biliary cirrhosis syndrome. Gastroenterology, 71, 450-456.

13) Herberman, R.B., Oldham, R.K. (1975) Problems associated with study of cell-mediated immunity to human tumors by microcytotoxicity assays. $J$. nat. Cancer Inst., 55, 749-753.

14) Lee, W.M., Reed, W.D., Michell, C.G., Galbraith, R.M., Eddleston, A.L.W.F., Zuckerman, A.J. \& Williams, R. (1975) Cellular and humoral immunity to hepatitis B surface antigen in active chronic hepatitis. Brit. med. J., 1, 705-708.

15) Lobo, P.I. \& Horwitz, D.A. (1976) An appraisal of Fe receptors on human peripheral blood $\mathrm{B}$ and L lymphocytes. J. Immunal., 117, 939-943.

16) Meyer zum Büschenfelde, K.H. \& Mieseher, P.A. (1972) Liver specific antigens. Purification and characterization. Clin. exp. Immunol., 10, 89-102.

17) Miller, J.F.A.P., Basten, A., Sprent, J. \& Cheers, C. (1971) Interaction between lymphocytes in immune responses. Cell. Immunol., 2, 469-495.

18) Miller, J., Smith, M.G.M., Mitchell, C.G., Reed, W.D., Eddleston, A.L.W.F. \& Williams, R. (1972) Cell-mediated immunity to a human liver-specific antigen in patients with active chronic hepatitis and primary biliary cirrhosis. Lancet, 2, 296297.

19) Mutchnick, M.G., Kawanishi, H. \& Hopf, U. (1976) Absence of liver specifie protein (LSP) in Chang cells by indirect immunofluorescence. Gastroenterology, 70., Part 2, 989.

20) Nielsen, J.O., Dietrichson, O., Elling, P. \& Christoffersen, P. (1971) Incidence and meaning of persistence of Australia antigen in patients with acute viral hepatitis: Development of chronic hepatitis. New Engl. J. Med., 285, 1157-1160.

21) Nonomura, A., Shintani, T. \& Ohta, G. (1978) Antibody-dependent cell-mediated cytotoxicity and hepatocyte membrane-fixed IgG in chronic active hepatitis. Gastroenterology, 74, 640-641.

22) Ohta, G., Nonomura, A. \& Nishimura, I. (1976) Leucocyte migration inhibition with inner and outer membranes of mitochondria and insoluble hepatocyte surface membranes prepared from rat liver in patients with chronic hepatitis and cirrhosis. Clin. exp. Immunol., 26, 491-504.

23) Parish, C.R. \& Hayward, J.A. (1974) The lymphocyte surface I. Relation between Fc receptors, C'3 receptors and surface immunogloublin. Proc. roy. Soc. B., 187, 47-63.

24) Paronetto, F. \& Vernace, S. (1975) Immunological studies in patients with chronic active hepatitis. Cytotoxic activity of lymphocytes to autochthonous liver cells grown in tissue culture. Clin. exp. Immunol., 19, 99-104.

25) Perlmann, P., Perlmann, H. \& Wigzell, H. (1972) Lymphocyte mediated cytotoxicity in vitro. Induction and inhibition by humoral antibody and nature of effector 
cells. Transplant. Rev., 13, 91-114.

26) Ruddle, N.H. \& Waksman, B.H. (1968) Cytotoxicity mediated by soluble antigen and lymphocytes in delayed hypersensitivity. 1. Characterization of the phenomenon. J. exp. Med., 128, 1237-1254.

27) Sherlock, S. (1976) Predicting progression of acute type-B hepatitis to chronicity. Lancet, 2, 354-356.

28) Smith, M.G.M., Golding, P.L., Eddleston, A.L.W.F., Mitchell, C.G., Kemp, A. \& Williams, R. (1972) Cell-mediated immune responses in chronic liver diseases. Brit. med. J., 1, 527-530.

29) Smith, M.G.M., Eddleston, AL.W.F. \& Williams, R. (1975) Immunological factors in the evolution of active chronic hepatitis and other autoimmune liver diseases. Clin. Gastroenterol, 4, 297-313.

30) Takasugi, M. \& Klein, E. (1970) A microassay for cell-mediated immunity. Transplantation, 9, 219-227.

31) Thomson, A.D., Cochrane, M.A.G., McFarlane, I.G., Eddleston, A.L.W.F. \& Williams, R. (1974) Lymphocyte cytotoxicity to isolated hepatocytes in chronic active hepatitis. Nature (Lond.), 252, 721-722.

32) Wands, J.R. \& Isselbacher, K.J. (1975) Lymphocyte cytotoxicity to autologous liver cells in chronic active hepatitis. Proc. nat. Acad. Sci. USA, 72, 1301-1303.

33) Wands, J.R., Perrotto, J.L., Alpert, E. \& Isselbacher, K.J. (1975) Cell-mediated immunity in acute and chronic hepatitis. J. clin. Invest., 55, 921 $\sim 929$.

34) Yata, J., Desgranges, C., Tachibana, T. \& De-The, G. (1973) Separation of human lymphocytes forming spentaneous rosettes with sheep erythrocytes. Biomedicine [express], 19, 475-478. 